IOWA SUPPLEMENTAL ENERGY CONSERVATION PLAN

$$
\text { FCOI-77RGO8117 }
$$

250--28.1(476) Purpose Coverage

28.1(1) This plan, known as the Iowa supplemental energy conservation purpose plan, is designed to provide conservation services to those consumers who would not otherwise be offered services under the statewide I-SAVE conservation plan (25) IAC Ch. 27). The provisions of the plan are tailored to the needs and concerns of the small to medium sized energy supplier and reflect a balance between effective conservation services, program participation and cost recovery ability

\title{
28.1(2) Coverage
}

This plan applies to all electric and gas utilities which are not covered under the I-SAVE plan and to all suppliers of fuel oil, propane and butane for home heating purposes. Participation in this plan will be on a voluntary basis.

a. Each utility and home heating supplier must notify the commission in writing of their intentions to participate in the plan. Energy suppliers may elect to participate at any time during the duration of the program.

(1) Any utility or home heating supplier may, at its discretion, elect to withdraw themselves from the plan at any time during the implementation of the program subject to the following provisions:

(b) A written statement from the energy supplier is submitted to the Commission. This will constitute formal with- 


\section{DISCLAIMER}

This report was prepared as an account of work sponsored by an agency of the United States Government. Neither the United States Government nor any agency Thereof, nor any of their employees, makes any warranty, express or implied, or assumes any legal liability or responsibility for the accuracy, completeness, or usefulness of any information, apparatus, product, or process disclosed, or represents that its use would not infringe privately owned rights. Reference herein to any specific commercial product, process, or service by trade name, trademark, manufacturer, or otherwise does not necessarily constitute or imply its endorsement, recommendation, or favoring by the United States Government or any agency thereof. The views and opinions of authors expressed herein do not necessarily state or reflect those of the United States Government or any agency thereof. 


\section{DISCLAIMER}

Portions of this document may be illegible in electronic image products. Images are produced from the best available original document. 
drawl and will become effective on the date specified in the notice.

(c) State that customers who have requested audits and who have requested the arranging services will continue to receive those accrued plan benefits, including conciliation.

(d) State that customers who have requested audits will be assured of receiving an audit and all requested benefits.

(2) All energy suppliers who elect to participate in the Iowa conservation plan will notify their industry representative of their intentions. The following associations have been designated program coordinators by the ISCC:

(a) Participating rural electric cooperatives contact:

Iowa Association of Rural Electric Coops 8525 Douglas

Suite \#48

Urbandale, Iowa 50322

(b) Participating municipal utilities contact:

Iowa Association of Municipal Utilities

520 Insurance Exchange Building

Des Moines, Iowa 50309

(c) Participating fuel oil dealers contact:

Iowa Independent 0il Jobbers Assn.

321 E. 6th Avenue

Des Moines, Iowa

(d) Participating LP gas dealers contact:

Iowa LP Gas Association

(Reserved)

$250--28.2(476)$ Definitions.

Unless otherwise stated, the definitions contained in the I-SAVE plan, 250 IAC 27.2, shall apply to terms used in this chapter. Other terms used are defined as follows: 
1. Participating energy supplier. The term "participating energy supplier" includes participating gas and electric utilities which are not "covered utilities" under chapter 27 IAC, and participating home heating suppliers.

2. Participating utility. The term participating utility shall mean an electric or gas utility which has elected to participate in the Iowa supplemental Energy Conservation Plan.

For those sections of Ch. 27 IAC which are included by reference in this plan, the term "covered utilities" shall refer to participating REC and municipal utilities. 250--28.3(476) Compliance and monitoring.

28.3(1). Compliance. Participating energy suppliers shall comply with the Iowa supplemental energy conscrvation plan.

28.3(2) The commission will be responsible for ensuring that all participating utilities:

a. distribute program announcements to all eligible customers in accordance with provisions in the state plan. The commission shall be informed by the participating utility or program coordinator of the schedule for distribution of announcements.

b. Follow all calculating and auditing procedures esta- . blished by the state of Iowa to provide customers with accurate audit information. The accuracy of the audit information will be monitored by requiring participating REC's and municipal utilities to submit data and calculations on a randomly selected audit. The ISCC may supplement the 
review with random spot checking of auditors by a state designated auditor.

c. Perform the arranging of service function in accordance with the Iowa conservation plan. This service shall be monitored by a periodic review of completed installations, consumer complaints, and the utilities annual program reports.

d. Perform the post installation inspection in accordance with plan requirements. The ISCC will periodically review johs that have resulter in audits; arrangements of servises and inspections to ensure that all program requirements are being satisfied.

e. Comply with the reporting and recordkeeping requirements established in the conservation plan.

f. The participating rate requlated utilities will comply with the accounting procedures and payments of costs as . directed by the ISCC. The review of the annual program report submitted by each participating REC and will determine compliance. In accordance with existing state law, the ISCC may institute formal investigations of accounting and auditing procedures. 250--28.4(476) Scope of benefits.

28.4(1) Eligibility. Customers' benefits under the Iowa conservation plan will be determined by the degree of participation in the plan by the individual customer. In order to obtain any benefits, the customer must, at a ,.. minimum, utilize at least one of the following services:

a. Arrangement of installation according to the procedures contained In section 28.8 (arranging installation). 
b. Arrangement of financing according to procedures established in section 28.9 (arranging financing).

c. Purchase of a program measure from a listed supplier who verifies in writing to the customer that the measure meets applicable program material standands and is covered by the program measures warranty.

28.4(2) Program benefits. A customer who utilizes the installation arranging service according to procedures outlined in the section 28.8 (arranging installation), is entitled to the following benefits:

a. A measure warranty for each program measure installed, except caulking and weatherstripping.

b. Installation of program measures that meet all applicable RCS material standards.

c. Installation of program measures that meet all applicable RCS installation standards.

d. Inclusion in the pool of customers from which random post installation inspections will be made.

e. Access to customers complaint proceedings, according to procedures in section 28.11 (consumer grievance procedure) of the state plan.

f.For listed suppliers, contractors, lenders, adherence to the listing requirements as outlined in section 28.9 (listing requirements) of the state plan. 
28.4(3) A customer who arranges financing through the participating energy supplier according to procedures in section 28.10 (arranging financing) in the plan, is entitled to benefit (e) and (f) above, in addition the customer may be eligible for the utility blling and repayment of loans as outlined in section 28 :

28.4(4) A customer who purchases program measures from a listed supplier is eligible for benefits (a), and (e) above, and supply of measures by a listed supplier that meets the supplier rcquirements in sertion 28.8 (listing requirements) of the conservation plan. When requesting benefits from the participating energy supplier, customers who purchase their own measures from a listed supplier must provide a copy of the supplier's document which identifies the program measures purchased.

250--28.5(476) Program announcements.

a. Participating REC and municipal utility shall send to each eligible customer a program announcement within six (6) months after electing to participate in the state conservation plan.

b. This program announcement shall be sent out every two years after the initial majling until January $1,1985$.

c. Each new customer, shall receive a program announcement within sixty (60) days of becoming a new customer, and every two years thereafter until January 1, 1985.

d. In order to minimize the number of duplicate announccments, the participating REC or municipal utility will not 
be required to send announcements to those customers who are eligible under the I-SAVE conservation plan for covered utilities.

e. The content of the program announcement shall contain the following elements, as a minimum:

(1) A list of all program and state measures with an estimate of savings in energy costs, which are likely to be produced in one year, expressed in ranges of dollars or percentages;

(2). A list of all energy conserving practices, a statement that they are of low or no cost, and an estimate of savings in energy costs, which are likely to be produced in one year, expressed in ranges of dollars or percentages and a statement to the effect that the total energy savings may he less than the sum of the cost savings projected for the individual measures:

(3) An offer and description of the:

(a) Program audit;

(b) Installation arrangement service;

(c) Financing arrangement service; and

(d) Contractor, lender and supplier lists.

The description of each service shall include information on how a' customer may obtain each service, the direct cost, if any, and the scope of benefits included in that service; (4) Inclusion of the following disclosure or its equivalent: "Energy savings depend on many factors. The estimates contained in the announcement are based on estimates for typical 
houses. Your costs and savings will be different if your house is a different size or type, if your family is a different size or if your energy using habits are different from those we assumed. The energy audit which we offer will provide more specific estimates for your house."

(5) A brief explanation of the benefits of the federal and state energy credits; and

(6) A brief description of the benefits of the weatherisation aooictance program for low income persons, 10 CFR Part 440 , and a brief description of who is eligible for such assistance.

e. No advertising for sale, installation, or financing by any supplier, contractor or lender of any energy conservation measure, renewable resource measure, state measure or energy conserving practice. If a participating. REC or municipal utility finances the sale or installation of such measures or practices, the program announcement may state so.

f. No information regarding any product which is not an energy conservation measure, a renewable resource measure, state measure or any energy conservation practice may be included in the program announcement.

9. All program announcements must be submitted for approval to the Iowa state commerce commission prior to aistribution.

h. The energy audits may be offered to customers on a conditional nondigcriminate basis. All customers who 
receive a conditional offer of any audit must receive an unconditional offer of an audit within two years.

i. The calculation procedures for the cost and savings estimates contained in the program announcement will be approved by the Iowa state commerce commission. This will assure that all program announcements in the state will be consistent.

j. Calculation procedures. (reserved)

k. All estimates in the program announcement will be based on recent prices and appropriate climatological data for the state. 250--28.6(476) Requirements for program audits.

28.6(1) Timing and preconditions.

a. Each participating utility shall provide a program audit to an eligible customer within sixty (60) days of an unconditional offer of an audit.

b. Each participating utility shall inform and provide to each new customer, upon request, a copy of any program audit done previously of the customers residence. If the eligible customer requests an additional audit and the previous audit had been performed within the previous two year period, such audit will be performed at active cost to the eligible customer.

c. Participating utilities are prohibited from preconditioning a program audit in any manner.

d. Participating utilities shall not discriminate unfairly among eligible customers in providing program audits. 
28.6(2) Content of program audit.

a. General. Each participating utility shall, at a minimum, offer to provide to each eligible customer a comprehensive program audit which addresses all energy conserving practices, energy conservation measures and renewable resource measures upon request by an eligible customer. In each program audit, the auditor shall determine which of the energy conserving practices would save energy in the residence, explain and emphasize the importance of such practices and recominend that they be performed before the installation of any measure. The auditor shall then. determine the applicability of each program measure in that residence. If a program measure is not applicable, then the requirements of this section to provide estimates of the cost and savings of installation in such residence need not apply.

b. Energy conserving practices. The following are defined as energy conserving practices for the purpose of this plan:

(1) Furnace efficiency maintenance and adjustments.

(2) Nighttime temperature setback.

(3) Reducing winter thermostat setting.

(4) Raising summer thermostat setting.

(5) Water flow reduction in showers/faucets.

(6) Reducing hot water temperatures.

(7) Reducing energy use when a home is unoccupied.

(8) Plugging leaks in attics, basements, crawl spaces, fireplaces, switch plates and wall plates. 
(9) Sealing leaks in pipes and ducts.

(10) Efficient use of shading.

c. Applicability of program measures.

(1) A program measure is applicable if installation of

the measure. is not in violation of federal, state or local

laws and ordinances:

(2) Specific program measures listed below are applicable

if the corresponding condition is met.

Measure

Caulking \& weatherstripping

Ceiling insulation

Wall insulation

Floor insulation

Water heater insulation

Duct and pipe insulation

Thermal windows

Heat-reflective and heatabsorbing window or door material

clock thermostat
Applicability Criteria

Existing caulking or weatherstripping is inadequate.

The difference between $R$ existing and $R$ program = eleven or more, and the building is not a mobile home.

There is no insulation in a substantial portion of the exterior walls and the building is not a mobile home.

There is no insulation in the floor over an unconditioned space.

The remaining useful life of the water heater appears to be three years or greater, and the auditor determines that conditioning of the area around the unit warrants consideration of the measure.

Ducts and pipes are located in an unconditioned area.

The residence does not have storm windows.

The residence has an existing room or central air conditioning

The residence has a thermostat or the existing furnace or central air conditioner is compatible with a clock thermostat. 


\section{Measure}

Passive solar space heating and cooling system: (i) passive solar direct or indirect gain glazing system

Passive solar solaria/ sunspace systems

Passive solar window heat gain retardants

Wind energy systems

Replacement furnaces or boilers

Electrical or mechanical gas ignition system

Oil furnace replacement burner

Vent opening modification

Replacement central air conditioner

\section{Applicability Criteria}

The living space of the residence has wither a south-facing ( + or -45 \% of true south) wall or an integral south-facing ( + or $-45^{r}$ of true south) roof which is free of major obstruction to solar radiation.

The living space of the residence has a south-facing ground level wall, which is free of major obstruction to solar radiation.

The living space of the residence has a south-facing ( + or -454 of true south) window that is not shaded from surmitei sunshine.

The lot is larger than .75 acres, there is no major wind obstructions and the tower can be sited at least fifty feet from the property line or right-of-way for electrical transmission or distribution lines.

The furnace is five years old or older.

Always applicable.

Always applicable.

The furnace combustion air is taken from a conditioned space.

The building has a central air conditioner that is five years or older.

28.6(3) Cost estimates. Estimates of energy cost savings and of installation costs provided as a result of a program audit shall be performed in the following manner:

(1) Actual measurements or inspections of the building shell and of the space heating, space cooling, and water heating equipment, shall be performed or verified on-site by the auditor. 
(2) Economic calculations shall be based on typical recent local electric rates, typical recent local fuel prices, typical recent local prices for materials and installation of program measures, and typical recent local climate data for the eligible customer's location.

(3) A solar domestic hot water system's cost shall be based on the calculation procedures contained in the current HUD intermediate minimum property standards supplement, solar heating and domestic hot water systems 4930.2, 1977 edition, U.S. Department of Housing and Urban Development or equivalent procedure approved by the state.

(4) Any cost and savings estimate for any applicable furnace efficiency modification to a gas or oil furnace or boiler shall be based on an evaluation of the seasonal efficiency of such furnace or boiler. This seasonal efficiency shall be based on an estimated peak (tuned-up) steady state efficiency corrected for cycling losses. Steady state. efficiency shall be derived either from manufacturer's design data and observation of furnace components or by calculation of the combustion efficiency of the furnace or boiler. Where visual observation by the auditor shows poor operation, calculation of combustion efficiency shall be made.

28.6(4) Procedure to assure the validity of the program audit.

The state shall approve all procedures of a participating energy supplier governing the measurements or inspections that an auditor must make in an eligible customer's residence and the calculations which must be performed in making 
energy cost savings estimates. Approval of such procedures by the state must be obtained prior to the distribution of program announcements.

28.6(5) Results of program audit.

Upon sompletinn of a program audit, the auditor shall provide the following information on-site, in writing to each eligible customer who receives a program audit.

(1) An estimate of the total cost (materials and labor), expressed in dollars or a range of dollars of installation by a contractor of each applicable program measure addressed in the program audil.

(2) An estimate of the total cost, expressed in dollars or a range of dollars, of installation by the customer of each applicable program measure, other than replacement central air conditioners and wall insulation, addressed in the program audit. A covered utility or participating home heating supplier shall not provide any estimate to any eligible customer of the cost uf purchase of furnace efficiency modifiratinns, devices associated with load management techniques, or wind energy devices for installation by the eligible customer.

(3) An estimate of the savings in energy costs, expressed in dollars or a range of dollars, which would occur during the first year from installation of each applicable program measure addressed by the audit.

(4) A clear indication to the eligible customers, through sample calculation or disclosure, that the total energy cost savings from the installation of more than one program 
measure may be less than the sum of energy cost savings of each measure installed individually.

(5) The following disclosure: "The procedure used to make these estimates have been evaluated by the state for accuracy. However, the actual installation costs you incur. and energy savings you realize from installing these measures may be different from the estimates contained in this audit report. Although the estimates are based on observations or measurements of your house, they are also based on assumptions which may not be totally correct for your household.".

(6) An estimate of the annual normal maintenance costs, if any, of each applicable program measure.

(7) The possible economic benefits to the eligible customer of existing federal and state tax incentives with, at a minimum, one sample of the effect of the tax benefit on the cost to the customer of installing one applicable energy conservation program measure and one applicable renewable resource program measure.

\section{$28.6(6)$ Audits of furnaces.}

a. Participating Energy suppliers shall coordinate the furnace portion of the audit to ensure that the most qualified person for each fuel type performs the furance. inspection.

b. When determination of seasonal efficiency or boiler requires a level of training or expertise beyond that possessed by the auditor or when cooperating home heating suppliers are not avaliable, the furnace portions of the 
audit need not be addressed.

28.6(7) Audits of renewable resource measures.

a. Participating energy suppliers shall at a minimum determine the applicability of renewable resource measures and when applicable provide written materials designed to inform the customer of the types and availability of such measures.

b. When site specific estimation of total installation coote and energy sayinga nf applicable renewable resource measures requires a level of lraining or expcrtice boyond that possessed by the auditor, the specific cost and 5 anings estimates need not be addressed.

c. A program audit addressing an applicable solar domestic hot water system shall include a description of the solar system assumed by the auditor in preparing energy savings estimates and shall include the following information:

(1). The square feet of the collector;

(2) The collector characteristics, including glazing materials and other collector materials;

(3) Any storage system needed, including the capacity of storage;

(4) Any freeze protection needed;

(5) The estimated percent of the water heating load to be met by solar energy:

(6) Any physical connections needed with existing heating systems;

(7) Any site preparation needed; and 
(8) If the results are based on a simulation, the following disclosure or its equivalent:

"The energy cost savings estimates you receive are based on systems which may be different from the ones you purchase. Also, these estimates were not determined using actual conditions but using simulated measurements. Therefore, the cost savings we have estimated may be different from the savings which actually occur."

d. A program audit addressing an applicable passive solar space heating and cooling system shall include:

(1) The generic description and a pictoral description of the particular system considered by the auditor;

(2) The estimated percent the heating load of the residence to be met by such a system;

(3) The approximate dimensions of the system;

(4) The characteristics of storage, including the recommended heat capacity; and

(5) The disclosure provided in paragraph $1.3(8)(\mathrm{h})$ of this subsection.

e. A program audit addressing an applicable wind energy device shall include:

(1) Installation cost estimates, based on the kilowatt rating of a commercially available wind device appropriate to the level of electricity consumed in the customer's residence;

(2) Estimates of energy cost savings, based on average yearly wind speeds and the specification of the selected wind device; 
(3) The auditor's best estimate of the average wind speed at the residence based on data available at the nearest wind measurement station; and

(4) The specifications of the wind device under consideration. 28.6(8) Additional information to be provided during an audit.

The auditor shall present the following information as a minimum to the eligible customer during, or upon completion of, the program audit:

a. An explanation of the benefils and services listed in the state plan and a brief description of how tho aligible customer can qualify for such benefits and services.

b. The lists of contractors, suppliers and lenders developed pursuant to the state plan for the applicable program measures.

c. An explanation of the benefits of the weatherization assistance program for low income persons, 10 CFR Part 440, and a brief description of who is eligible for such assistance.

$\therefore 8.6(9)$ Prohibitions ard disclosure required for program. audits. The auditor shall comply with the following:

a. The auditor is prohibited from estimating, as part of any program audit provided pursuant to the state plan, the costs or energy cost savings of installing any product which is not an energy conserving practice or a program measure. b. The auditor is prohibited from recommending any supplier, contractor or lender who supplies, installs, or finances the sale or installation of any program measure, if such recommendation would unfairly discriminate among such 
suppliers, contractors or lenders. If the energy supplier, which arranged the audit, supplies, installs or finances the sale or installation of program measures, the auditor may so state.

c. Any unfair discrimination among program measures is prohibited.

d. Each energy auditor shall provide the eligible customer with a written statement of any substantial interest which the person or the person's emplover has, directly or indirectly; in the sale or installation of any program measure.

28.6(10) Preaudit informational questionnaire. A participating REC or municipal utility may request an eligible customer who has requested a program audit to submit information in the form of a questionnaire provided such questionnaire is not a precondition of a program audit and the questionnaire is approved by the state.

28.6(11) Class B audits. A participating energy supplier may offer class $B$ audits in conjunction with the conservation program provided that:

a. Class B energy audits address energy conserving practices, applicable conservation and program measures;

b. Class B energy audits explain the energy conserving practices, emphasize the importance of these practices, and, recommend that they be performed before installation of any measure; 
c. Class B energy audits meet the requirements for program audits contained elsewhere in this plan and contain procedures to assure the validity of the audit as provided for elsewhere in this plan with respect to program audits. However, all references to measurements and inspections by the auditor shall be treated as references to measurements and inspections by the customer.

d. The class B audit provides to the eligible customer suhstantially the same information required as part of a prograul audit deseribed eleewhere in this plan;

e. The class $B$ audit provides to the eligible customer the additional information required as part of a program audit described elsewhere in this plan;

f. The Class B audit offers the lists of contractors, suppliers and lenders developed pursuant to the plan;

g. The Class B audit contains the same prohibitions required elsewhere in this plan, except that references to the program audit shall be deemed to refer to the Class $B$ audit and references to the auditor shall refer to the entity providing the Class $B$ audit;

h. The participating energy supplier providing the class $B$ audit, attempts to contact the eligible customer, by telephone or otherwise, if the information sent by such. customer is incomplete or internally inconsistent, in order to attempt to correct or make complete the information. 
250--28.7(476) Qualification of program auditors.

28.7(1) General.

Each person who performs a program audit pursuant to this plan shall:

a. Be a certified auditor according to the applicable procedures in 28.7.(4) of the state plan or meet minimum auditor qualification requirements applicable to the portion of the audit which the auditor conducts, and;

b. Be under contract or subcontract to, be an employee of, or be an employee of a contractor or subcontractor to, a participating energy supplier.

28.7(2) Minimum auditor qualification requirements. The person or persons conducting the audit shall individually or collectively have the following qualifications:

a. Complete a state-approved training course that provides the following:

(1) General understanding of the three types of heat transfer and the effects of termperature and humidity on heat transfer.

(2) General understanding of residential construction terminology and components.

(3) General knowledge of the operation of the heating and cooling systems used in the residential building.

(4) General knowledge of the different types of each applicable program; of the advantages, disadvantages, and applications of each; and of any installation standards prescribed for the RCS program. 
(5) Capacity to conduct the audit according to the procedures described in section 1.2 including: Familiarity with energy conserving practices prescribed in the state plan; capability of determining applicable program measures, proficiency in audit procedures tor each applicable program measure.

(6) Where a furnace efficiency modification is an applicable program measure, and the source of fuel for the oxisting furnace or boiler is either gas or oil, a working ability tu calculatc the steady state efficiency of the furnace or boiler as required by section 1.4 .

(7) Where a renewable resource measure, other than wind energy devices, is an applicable program measure, an understanding of the nature of solar energy and its residential applications, including: insolation, shading, heat capture and transport, heat transfer for hot water.

(8) Where a wind energy device is an applicable program measure, an understanding of the nature of wind energy and its residential applications, including: wind availability, effects of obstructions, wind capture, power generation, interfaces with residential and utility power lines.

28.7(3) Examination. Successful completion of training requirements shall be demonstrated through written or practical examinations administered by the training organization and approved by the state.

28.7(4) Certification. A program auditor may be certified by the state through any of the following: 
a. By satisfying training and examination requirements for all portions of the program audit.

b. By satisfying the examination requirements for all portions of the program audit, if the utility's existing training procedure adequately satisfies the requirements 0 of this section.

c. By reciprocity with other states which have substantially similar certification requirements upon review of the individual auditors qualifications. The state may require successful completion of wirtten or practical examination before granting reciprocity certification.

\section{$250--28.8$ Listing.}

See chapter 27.9 IAC Listing.

$$
\text { 裉: }
$$

250--28.9 Arranging installation.

28.9(1) Each participating utility will arrange installation of any program measure upon request by any eligible customer.

28.9(2) These arrangement services will consist of the following:

a. Distribute lists of contractors and suppliers from the master record to all customers requesting it;

b. Assist the customer in obtaining answers to his questions regarding installation;

c. Advise low income, elderly, and handicapped customers of existing speclal programs available to meet their needs in the area of installation of program measures; and 
d. Provide materials and program measures specifications sheet for those recommended program measures as determined by the auditor. The specification sheet will serve as a bid specification stating the exact need and the applicable standards to facilitate comparative bids. When soliciting bids from listed contractors, the eligible customer must present an bid specification to the contractor, on which the contractor may make the appropriate notations. (see appendix)

28.9(3) Eaoh participating utility will pruvide sucl arrangement service within thirty (30) days from receipt of a request for such service.

28.9(4) Each participating utility when arranging installation of program measures, shall not recommend, select or provide information regarding any supplier or contractor if such recommendation, selection, or information would unfairly discriminate among suppliers and contractors of program measures. Covered utilities that supply or install program measures may so inform the customers.

28.9(5) Each participating utility when arranging installation of program measures, is prohibited from discriminating unfairly among eligible customers, among suppliers, among contractors, or among suggested measures.

28.9(6) Each participating utilitiy shall not arrange installation with any person not in the master record.

28.9(7) Each participating utility shall not arrange, in conjunction with the plan, the installation of any measure that is not a program measure. 
250--28.10(476) Arranging financing.

28.10(1) Each participating utility will arrange financing for the supply or installation of any applicable program measure upon request by any eligible customer.

28.10(2) These arrangement services will be as follows:

a. Distribute lists of lenders from the master record to all eligible customers requesting it;

b. Upon request assist the eligible customer in obtaining answers to his questions regarding financing;

c. Advise low income, elderly, and handicapped eligible customers of existing special programs available to meet their needs in the area of financing of program measures; and

d. Provide common credit application form and assist in preparation of said form when requested. (see appendix)

28.10(3) Each participating utility will provide the arranging service thirty. (30) days from receipt of a requeșt for such service.

28.10(4) Each participating utility when arranging financing for the purchase or installation of program measures, will not recommend, select or provide information regarding any lender if such recommendation, selection or information would unfairly discriminate among that finance the purchase or installation of program measures. Participating utilities that finance program measures may so inform the customers.

28.10(5) Each participating utility when arranging financing of program measures, is prohibited from discriminating 
unfairly among eligible customers, among suppliers, among contractors, or among program measures.

28.10(6) Participating utility shall not arrange financing for supply or installation of program measures with any lenders not in the master record.

250--28.11(476) Post-installation inspection.

28.11(1) Inspections of randomly selected installations 3holl bc porformod within a reasonahle period of time after completion. Any of the following methods may be utilized for performance of this function:

a. Inspections by qualified energy auditors.

b. Inspections by independent inspectors under contract.

c. Inspections arranged between energy suppliers.

d. Where existing and active, inspections by certified governmental subdivision inspectors operating under permitinspection statues or ordinances.

e. Certified compliance with industry approved installation standards.

28.11(2) Presentation of post-installation results/ mandatory and random inspections.

a. Within 10 working days of the inspection, a certificate of inspection will be sent to:
(1) The customer;
(2) The installer;
(3) The lead agency; and
(4) The participating energy supplier. 
b. A "certificate of inspection" containing all required information shall be completed by the inspector. A standard certificate shall be developed by the entity responsible for administering the post-installation inspection.

c. Any violations will be immediately reported to those entities designated in this subsection.

d. The certificate of inspection will certify that the inspected measures conform to applicable material and installation standards. However, the certificate of inspection does not address nor. insure against consequences of the use of materials or their installation. Such consequences remain the responsibility of the manufacturer or installer.

250--28.12(476). Consumer grievance procedures.

The consumer grievance procedures outlined in Chapter: 27.13 IAC shall be available to all eligible customers under this plan. termination of service.

28.13(1) When billing a customer for costs associated with program services, a participating energy supplier shall:

a. Identify the charges and list them separately on the customers utility bill or other periodic bill.

b. Itemize the direct charges, if any, to a customer for the program audit, arrangement of services or post-installation inspection. 
c. Allow the customer to repay direct payment charges made by the energy supplier in the payment to the supplier for utility or fuel service.

28.13(2) In the case of a loan made by a participating energy supplier under this plan, the pallicipating onergy supplier shall permit a customer to include repayment of that loan in the payment of the customer's periodic utility or fuel bill over a period of not less than three years, unless the customer chooses a shorter repaymont period. A participating cnergy supplier shall not be required to provide for monthly payments of less than five dollars.

28.13(3) A listed lending institution may require the lump sum payment of outstanding principal and interest in default by an eligible customer.

28.13(4) No penalty shall be imposed by the lender for payment of all or any portion of the outstanding loan amount prior to the date such payment would otherwise be due.

28.13(5) No participating energy supplier shall terminate or otherwise restrict utility or fuel service to any customer for default by such customer of payments due for services under the Iowa conservation program.

28.13(6) Alternative methods. To the extent that the, participating energy supplier considers these procedures unduly burdensome, it may petition the ISCC for a waiver. Included in the petition shall include a description of an alternate method which the energy supplier feels is compatible with current procedures. 
$250--28.14(476)$ Accounting.

28. 14 (I) General procedures. All costs and revenues directly attributable to this plan as implemented by the Iowa state commerce commission shall be accounted for on the books and records of a utility separately from all amounts attributable to activities other than the implemented conservation program. The utilities may account for other conservation efforts (i.e., efforts outside those specified in the implemented program) separately but must retain the ability to segregate the costs and revenues specifically attributable to the implemented program.

28.14(2) Uniform system of accounts.

a. Utilities subject to the jurisdiction of the federal energy regulatory commission (FERC) shall utilize the uniform system of accounts as prescribed in Title 18, CFR Parts 101, 104,201 and 204 .

b. Rural electric cooperatives shall utilize the uniform system of accounts as. prescribed by the rural electrification administration (REA) in Title 7, CFR Part 1701, Appendix A.

c. Other participating utilities shall adopt accounts within their existing accounting system with the attributes of the appropriate accounts prescribed herein.

28.14(3) Program expenses for rate regulated utilities.

a. All amounts expended by a participating rate regulated utility for the implemented conservation programs shall be charged to the accounts specifically identified for such use by FERC or REA. If no such account is so specified, the applicable expenses shall be charged to unique subaccounts 
within account 908, customer assistance expenses, or its successor.

b. Appropriate records shall be maintained under this account to permit ready identification of costs that are required to support the reporting requirements specified in section 28.15 (reporting). This will, at a minimum, allow rcady identification of costs attributable to:

(1) Program information and

(2) Program audits (by type)

c. Costs may include:

(1) All amounts expended by a rate regulated utility for the program announcement and all public education and program promotion directly related to providing information about a utility's program;

(2) All amounts expended by a rate regulated utility for labor and materials in connection with the purchase or installation of any energy conservation or renewable resource measure;

(3) All amounts expended by a rate regulated utility to perform administrative and general duties directly related to the conservation program including those associated with program audits, list distribution, customer billing services, and "arranging." These administrative costs may include any costs the utility incurs if it conducts random postinstallation inspections required by section 28.11 (postinstallation inspection) and conciliation conferences required by section 28.12 (consumer grievance procedures); and 
(4) All amounts expended by a utility to perform project management duties directly related to the conservation program including areas such as:

a. Program audits;

b. Arranging for a lender to make a loan to an eligible customer to finance the purchase and installation costs of energy conservation and renewable resource measures, including the costs of arranging repayment of the principal and interest of a loan as part of the periodic bill; and

c. Arranging to have the program measures installed.

28.14(4) Program revenues for rate regulated utilities.

a. All revenues or billed income, received by a utility, attributable to the implemented conservation program shall. be charged to the accounts specifically identified by FERC or REA. If no such account is so specified, the applicable revenues shall be charged to unique subaccounts within account 456 , other electric revenue (for electric utilities) or account 495, other gas revenues (for gas utilities) or their successors.

b. The revenues so collected shall support the reporting requirements specified in section 28.15 (reporting). This will, at a minimum, allow ready identification of revenues resulting from program audits and the direct sale or installation of any energy conservation or renewable resource measure'covered by this program.

28.14 (5) Alternative methods. To the extent that a utility considers these accounting requirements cause an 
unreasonable hardship or expense, that utility may petition the commission for approval of an alternative method that accomplishes similar goals.

$250--28.15$ Reporting.

28.15(1) General reporting guidelines. The purpose of reporting guidelines is to ensure that'sufficient information is collected and submitted to the commission to permit a full analysis of the conservation program. Recognizing the difficulty and expense that amy small and medium sized energy suppliers face in projecting effects of specific conservation practices on system costs and patterns of energy use, the commission will utilize information provided in existing reports whenever possible. Additional information may be supplied individually by participating energy suppliers or collectively through program coordinators.

28.15(2) The following information shall be filed with the commission no later than June 1, 1981, and annually thereafter:

a. The approximate number of eligible customers and, if available, the percentage of those customers for whom the energy suppliers is the primary heating fuel supplier.

b. A copy of the program announcement distributed to eligible customers.

c. The number of eligible customers who have requested each service and the number of requests the utility has fulfilled, including the number of program audits performed; 
the number of installations arranged by the energy supplier; the number of loans arranged by the energy supplier, the number of customers, if any, who are using the energy supplier's billing service or repayment of loans; the number of installations, if any, of program measures which the energy supplier supplied, installed, or financed.

d. The number and results of post-installation inspections conducted according to section 28.11 (post-installation inspection).

e. The number and function of people assigned to the energy supplier's program including part-time employees.

f. The costs incurred by the energy supplier or home heating supplier in providing each service under the residential conservation service program including separately those costs paid by individual customers for services received and those costs paid by all ratepayers.

28.15(3) Information concerning other conservation programs. Information concerning other conservation programs conducted by energy suppliers eligible to participate under the plan shall be filed with the commission as part of the year end report. In addition, the commission may direct a representative number of small and medium sized energy suppliers to file conservation plans which substantially meet the requirements of Chapter $27.16(2)$ IAC, of the I-SAVE plan.

\section{0--28.16 Recordkeeping.}

28.16(1) Responsibility. Energy suppliers shall be responsible for maintaining records sufficient to support the 
reporting requirements identified above or as otherwise approved by the commission.

28.16(2) Other specific requirements. Further, the following records shall be maintained for the periods indicated. These records shall be made available to the commission or other designated personnel upon request:

a. The name and address of each eligible customer who receives a program audit, which shall be kept for five years from the date of such program audit.

b. A copy of the data collected during the audit, and a ", copy of the estimates of costs and savings presented to the customer, which shall be kept for five years from the date of such program audit.

c. The name and address of each eligible customer for whom a utility arranged installation or financing of a program measure, which shall be kept for five years from the date of such arrangements.

d. The amount and cost of fuel purchased each month or other billing period for the twelve months prior to and the twelve months following each program audit for each eligible customer, which shall be kept two years from the data of such program audit.

e. The names of individuals who have met the qualification criteria described in section 28.7 .

28.16(3) Alternative recordkeeping guidelines. To the. extent that an energy supplier considers these recordkeeping requirements cause an unreasonable hardship or expense, that 
energy supplier may petition the commission for approval of an alternative method with which it can reasonably comply. The specific information to be supplied under an alternative method should be identified. As much information as possible should be provided. 
RECEIVED BY TK OCT 311980 